\title{
Kerklike bediening aan die postmoderne stadsmens
}

\author{
I.J. Olivier \& H.J.M. van Deventer \\ Skool vir Basiese Wetenskappe \\ Vaaldriehoekkampus, Noordwes-Universiteit \\ VANDERBIJLPARK \\ E-pos: sakkie@lifecf.co.za \\ E-pos: bybhjmvd@puknet.puk.ac.za
}

\begin{abstract}
Church ministry to post-modern city dwellers

The world today is characterised by postmodernism and urbanisation. Both these processes have a serious impact on the world as we know it - on social life, and also on the ministry of the church. Working from a practical-theological foundation, the church is defined as a "called community of believers". The issue, however, is how this community should effectively and practically live out their faith in an urbanised post-modern world. This issue is investigated and suggestions in this regard are made.
\end{abstract}

\section{Opsomming}

Kerklike bediening aan die postmoderne stadsmens

Die wêreld van vandag word gekenmerk deur postmodernisme en verstedeliking. Albei hierdie prosesse het 'n groot impak op die wêreld soos ons dit ken, op sosiale strukture en ook op kerklike bediening. Vanuit 'n prakties-teologiese fundering word die kerk gedefinieer as 'n "geroepe gemeenskap van gelowiges". Die vraag is hoe hierdie gemeenskap hulle geloof prakties en effektief uitleef in 'n stedelike, post-moderne wêreld. Hierdie artikel ondersoek hierdie vraag en doen voorstelle in hierdie verband aan die hand. 


\section{Inleiding}

Die veranderinge in tydgees, veral in die Westerse wêreld, het al so gemeenplasig geword dat die begrip "postmodernisme" as 'n modewoord beskryf kan word. Benewens hierdie veranderinge het die spoed van verstedeliking ook bygedra tot 'n groot ommekeer in die tradisionele bestaan. Albei hierdie sake sal noodwendig 'n invloed op die kerk uitoefen.

In hierdie artikel word hierdie sake, te wete postmodernisme en verstedeliking, met mekaar in verband gebring wanneer ondersoek ingestel word na kerklike bediening in 'n postmoderne konteks, en veral gefokus word op die bediening aan die stadsmens. In hierdie ondersoek word die verskynsels van postmodernisme en verstedeliking eerstens kortliks beskryf. Tweedens word gelet op die wese van die kerk, veral vanuit 'n reformatoriese oogpunt, asook wat die invloed van die postmodernisme en verstedeliking op die kerk is. Verder word vanuit prakties-teologiese oorwegings aandag gegee aan brandpunte in die huidige wêreld en laastens word gelet op wyses waarop die kerk kan aanpas om relevant te wees in 'n postmoderne, stedelike omgewing.

\section{Postmodernisme en verstedeliking as eietydse verskynsels}

\subsection{Die oorgang vanaf die modernisme na die post- modernisme}

Volgens Naudé (1992:98) verwys die term postmodernisme op filosofiese vlak na die beweging waarin fundamentele kritiek teen die modernisme en tradisie van die Verligting uitgespreek word. Neutjens (2000:286) meen een van die algemeenste kenmerke van die postmodernisme is dat rasionaliteit nie langer gesien word as die enigste geldende basis waarop kulture gebou word nie. Hierdie artikel sluit aan by Neutjens (2000:283) deur die postmodernisme te beskou as die proses om verby die (rasionele) grense van modernisme te beweeg. So beskou, is die verskynsel "postmodernisme" steeds vaag, maar Janse van Rensburg (2001:34) wys daarop dat verskille tussen belangrike eksponente van hierdie verskynsel enige nadere definisie bemoeilik. Oral waar daar egter met verantwoordelikheid gekyk word na die toekoms, moet die simptome van hierdie belangrike kulturele verandering, wat in verskeie velde manifesteer, ernstig bejeën word. 
Postmodernisme het grootliks te make met die verandering van die wyse waarop die mensdom homself en sy wêreld verstaan. Waar die modernisme 'n vertroue in rede en wetenskap as 'n weg na die waarheid en vervulling voorgestaan het, het die postmodernisme 'n wantroue in hierdie rasionele velde. Aan die hand van Olthuis (1999:140-152) kan die volgende opsomming gegee word:

- in die modernisme is die realiteit logika; vir die postmodernisme is die lewe "meer as logika";

- die modernisme is meer rigied in strukture, geslote argumente, eenheid en eenvormigheid, stabiliteit, veiligheid, beheer, stelsels en grense, terwyl die postmodernisme vryheid, oop argumente, diversiteit, verandering, risiko en verhoudinggesentreerdheid voorstaan.

Dit is moeilik om presies te bepaal wanneer die postmodernisme as 'n dominante wêreldbeeld in die Weste na vore getree het en Janse van Rensburg (2001:13) wys daarop dat die meeste grondliggende idees van die postmodernisme reeds vir 'n baie lang tyd die rondte doen. Binne die omvangryke korpus van wetenskaplike literatuur oor die postmodernisme vind Janse Van Rensburg (2001:13) 'n verdere gemeenskaplike faktor. Daarvolgens is realiteit in 'n konstante toestand van flux (vloeibaarheid), met ander woorde niks bly staties nie. Dit veroorsaak die dilemma dat die konsep realiteit nooit gedefinieer kan word nie. Skrywers soos Nietzsche, De Saussure, Heidegger, Levi-Strauss, Foucault, Derrida en Lyotard, het volgens Janse van Rensburg (2001:13-34) almal deel aan die wortelvorming van die boom van postmodernisme en - alhoewel hulle wyd uiteenlopende idees het - bind bogenoemde gemeenskaplike faktor hulle tog saam. Tesame met die besef dat realiteit in 'n konstante toestand van flux is, het daar in die twintigste eeu 'n bewustheid ontwikkel aangaande die tekortkominge van wetenskap en rasionaliteit (Nash, 1997:17). Gebeurtenisse soos die twee wêreldoorloë, die Nazi's se etniese reiniging, die atoombomaanvalle op Hiroshima en Nagasaki, en kernkragrampe by Tjernobil en Three Mile Island het alles bygedra tot die erkenning dat die menslike verstand en vermoëns (rasionalisme) alleen nie die wêreld se probleme kan oplos nie en dikwels eerder daartoe bydra (Du Toit, 2000:51-52).

Die feit dat die fondament van die modernisme, naamlik 'n vertroue op wetenskap en wetenskaplike metode, asook die transendentale gesag van die rede (Adam, 1995:15) begin bevraagteken is, saam met die erkenning van die invloed van vooronderstellings op wetenskaplike werk (Adam, 1995:13) het 'n verdere kenmerk van 
die postmodernisme blootgelê: 'n verdraagsaamheid teenoor pluralisme. Verskillende godsdienstige, kulturele en politieke wêreldbeelde het as gevolg van die grootskaalse verbetering van vervoeren kommunikasiestelsels met mekaar in aanraking gekom en op mekaar begin inwerk. Die mens het blootstelling gekry aan 'n global village (Du Toit, 2000:58). Dit het 'n oorgang vanaf 'n enkele godsdienstige en kulturele wêreldbeeld na 'n pluralistiese, multigodsdienstige en multikulturele wêreldbeeld meegebring. Die moderne tradisionele Westerse omgewing se blootstelling aan en infiltrasie deur ander wêreldbeelde het daartoe gelei dat "waarheid" relatief geraak het binne hierdie konteks. Op rasionele vlak kon nie bewys word dat een waarheid of wêreldbeeld noodwendig "beter" is as ' $n$ ander nie. Binne hierdie konteks het nuwe kommunikasiekanale soos satelliettelevisie en veral die internet ander wêrelde tot binne in mense se huise gebring en het die kerk in 'n groot mate die "hekwagterrol" wat dit vroeër in 'n eendimensionele wêreld oor lidmate kon uitoefen, verloor.

Binne spesifiek 'n Suid-Afrikaanse konteks het die oorgang na 'n demokratiese politieke bestel ook 'n groot impak gehad. 'n Nuwe samelewingsorde is daargestel waarin met vorige grense, wette en geslote stelsels weggedoen is. In die nuwe samelewingsorde speel veral die Afrikaanse kerke 'n baie minder prominente rol as vroeër (Du Toit, 2000:57).

Al hierdie veranderinge is net soos die veranderinge wat die oorgang van 'n pre-modernistiese na 'n modernistiese samelewing gekenmerk het (Adam, 1995:1-3) nie bloot 'n modegier van verbygaande aard nie. Dat hierdie veranderinge in wese struktureel en blywend van aard is, word onderstreep deur die feit dat outeurs soos Janse van Rensburg (2001:35-63) die langste hoofstuk in sy boek oor die implikasies van postmoderne denke - spesifiek vir die teologie - wy aan 'n kritiese evaluering van hierdie verskynsel. Adam (1995:xiii) wys in sy werk daarop dat selfs die felste kritici van die postmodernisme erken dat hierdie verskynsel 'n groot impak het op die hedendaagse filosofie, teologie en Bybelinterpretasie. Du Toit (2000:59) voer aan dat die oorgang na die postmoderne era nog nie ten volle voltrek is nie, maar merk op dat wanneer dit gebeur het, daar iets "onherroeplik anders met 'n nuwe struktuur van denke" sal bestaan.

Nadat daar baie kortliks gekyk is na enkele kenmerke van die postmodernisme en gesien is hoedat hierdie verskynsel besig is om 'n fundamentele verandering in denke in veral die Westerse wêreld 
teweeg te bring, word vervolgens gelet op die proses van verstedeliking.

\subsection{Die proses van verstedeliking}

Tans is die verstedelikingsproses steeds 'n wêreldwye verskynsel in die ontwikkelde en ontwikkelende wêreld. Die redes vir die huidige proses van verstedeliking sluit onder andere die volgende in: die behoefte aan kwaliteitgesondheidsorg en opvoeding, natuurlike geboortegroei, die persepsie dat die algemene lewe in stedelike gebiede "beter" is, die moontlikhede van werk, die groter netwerk van ekonomiese en sakeondernemings-infrastruktuur, politieke besluite en immigrasie (vgl. Jenkins, 1997:55). Hierdie redes vind weerklank in Kok en Gelderblom (1994:13-29) se opsomming van die terreine waarin die uitdagings vir die beplanning van stedelike gebiede lê, naamlik: toegang tot geleenthede, bekostigbare fasiliteite en dienste, en die voorsiening in mense se basiese behoeftes.

Jenkins (1997:54) voer die ontstaan van stede terug na die landbouera in die menslike ontwikkeling. Dit het 'n dramatiese verandering teweeggebring vanaf 'n jagter-/versamel-kultuur na gesofistikeerde omgewings waar meer komplekse strukture, burokrasie en weermagte georganiseer kon word (Jenkins, 1997:54). Stede het veral vanweë hulle rol as politieke en ekonomiese middelpunte die sentra van verdere ontwikkeling geword. Nuwe klasse mense soos soldate, onderwysers, politici en handelaars het ontstaan.

Heelwat later, tydens die Industriële Revolusie, is die mens se produksievermoëns vergroot deur die vinnige ontwikkeling van die tegnologie. Hierdie ontwikkeling het 'n golf van migrasie na stedelike gebiede tot gevolg gehad. Groot ekonomiese voordele het gevolg, kennisvlakke het gestyg en die tegnologie het voortgestu. In die algemene stedelike lewe van vandag word die bates van die tegnologie - dinge soos elektrisiteit, telefone en toegang tot drinkwater - algemeen aanvaar. Fourie (2000:14) wys daarop dat die gebruikmaking van die tegnologie begin het met die aanvanklike verskaffing van lig, maar spoedig ontwikkel het na masjinerie en huishoudelike hulpmiddels soos yskaste, mikrogolfoonde, televisiestelle en rekenaars. Net so sal verdere tegnologiese ontwikkelings die menslike bestaan verder verander. Stede in ontwikkelde lande word reeds gekenmerk deur supersnelweë, sellulêre netwerke, indrukwekkende argitektuur en sneltreine. Verder wys Fourie (2000: 14) daarop dat die internet-infrastruktuur die mens se lewe net so drasties sal verander as wat die elektrisiteitsinfrastruktuur gedoen het. 
Die verstedelikingsproses het egter met probleme gepaard gegaan. 'n Verval in tradisionele waardes was aan die orde van die dag, behuisingsprobleme het gevolg en alkoholisme, prostitusie en misdaad het deel geword van die algemene bestaan (Jenkins, 1997:54). Die impak van MIV/Vigs moet ook al hoe meer in ag geneem word by verstedeliking. Die huidige twaalf miljoen MIV/Vigswesies wêreldwyd sal binne 'n verstedelikingskonteks 'n nuwe uitdaging wees, terwyl die uitdaging van werkloosheid sal verander na een van ' $n$ te vinnige omset van werkers (Fleshman, 2001:1). Die daling in lewensverwagting van veral volwassenes sal ook enorme druk op die sosiale en welsynstrukture binne die stad plaas.

Hierdie probleme het veral betrekking op sosiaal-maatskaplike sake en stel groot uitdagings aan owerhede, maar ook aan die kerk. Van der Walt (1992:27-29) wys daarop dat die verstedelikingsproses ook negatief op die kerk inwerk vanweë die sekularisasie en godsdienstige verval wat met verstedeliking saamhang. In die volgende afdeling sal in meer besonderhede en vanuit 'n prakties-teologiese hoek aandag gegee word aan die invloed van die postmodernisme en verstedeliking op die kerklike bediening.

\section{Die invloed van die postmodernisme en verstedeliking op kerklike bediening}

\section{1 Prakties-teologiese besinning}

Volgens Heyns en Pieterse (1991:9) vra die Praktiese Teologie na die teorieë wat ten grondslag lê van die kommunikatiewe geloofshandelinge in diens van die evangelie. Hierdie teorieë word krities beoordeel en - wanneer nodig - word nuwe teorieë ontwikkel. Dit geld vir alle geloofshandelinge van mense waarvan die meeste binne die aktiwiteite van die gemeente voltrek word. Dit sluit handelinge rondom die erediens, die onderrig aan lidmate en kinders, die pastorale versorging van mense, bepaalde dienste aan mense, die prediking en die getuienisaksie van mense in. Heyns en Pieterse (1991:8) wys daarop dat Praktiese Teologie daardie deel van die teologie is wat die ontmoeting tussen God en mens ondersoek en veral gefokus is op die rol van mense binne hierdie ontmoeting. Praktiese Teologie is geïnteresseerd daarin of die prediker die gehoor en hul konteks, dit is hul leefwêreld en denkwêreld, hul verwagtings, vrese, en hul belewenis van God, reg verstaan sodat die prediker die boodskap doeltreffend aan hulle kan kommunikeer. Praktiese Teologie is dus 'n studie van die handelinge van mense wat daarop ingestel is om ander mense te help om God te ontmoet en met God en medemens in gemeenskap 
te lewe. Praktiese Teologie het te doen met daardie geloofshandelinge wat doeltreffend met ander kommunikeer sodat ruimte geskep kan word vir mense om God te ervaar in hierdie wêreld. Hierdie definisies verwys - veral wat prediking betref - na die mens en sy/haar leefwêreld. In 'n meer onlangse publikasie toon Pieterse (2002:77) egter aan dat die algehele studieveld van die Praktiese Teologie afgestem is op ' $n$ bemiddelingsrol tussen die mens se leefwêreld en die Christelike tradisie.

'n Beter verstaan van wat Praktiese Teologie behels, dra by tot die duideliker verstaan van die kerk se uitdaging in 'n postmoderne, stedelike omgewing. Indien Praktiese Teologie die teorieë ondersoek wat ten grondslag lê van kommunikatiewe geloofshandelinge in diens van die evangelie, en dit poog om rekening te hou met die wêreld waarbinne die hoorders hulself bevind, dan sou die gevolgtrekking wees dat die prakties-teologiese teorieë opnuut beoordeel moet word binne die konteks van verstedelikings- en postmoderne prosesse. Breytenbach en Pieterse (1992:101) wys daarop dat een van die belangrike insigte van die Praktiese Teologie juis is dat teorieë vir die praktyk uitgespel, ontwikkel en ontwerp moet word (vgl. Pieterse, 2002:78).

Naudé (1992:99) is van mening dat elke tyd nuut moet dink en praat oor die evangelie. Hoe sou die handelinge in diens van die evangelie lyk om ruimte te maak vir mense om God te ervaar binne die hedendaagse konteks? Dat verstedeliking en die postmodernisme deel is van die kontekste waarbinne groot getalle van die mensdom hulself nou bevind, is reeds belig. Dat daar dus ' $n$ behoefte bestaan aan die aktualisering van bestaande teorieë vir die uitvoering van die gelowiges se geloofshandelinge binne die wêreld waarbinne hul leef, is duidelik. Heitink (1993:18-19) pleit vir 'n verstaan van Praktiese Teologie wat die Christelike geloof wil bemiddel midde-in die praxis van die samelewing. Hierdie benaderingswyse impliseer 'n teologie wat ontwikkel word vanuit die gesekulariseerde mens se kontekstuele ervaringswêreld. Die feit dat daar reeds die afgelope aantal jare so baie oor kerkvernuwing gedink is, beklemtoon verder hierdie behoefte aan die aktualisering van teorieë (vgl. Vorster, 1993:523; Shawchuck \& Heuser, 1993: 167; Bakke \& Hart, 1987:59).

Alvorens gelet word op die kerk se posisie en roeping te midde van 'n verstedelikende en postmoderne wêreld, word die aandag bepaal by die wese van die kerk. 


\subsection{Die kerk as saamgeroepte gemeenskap van gelowiges}

Om hierdie deel van die artikel te fundeer, is dit belangrik om eerstens 'n basisteorie van die "kerk", soos verstaan uit die Bybel, te omskryf. Daar word met ander woorde aandag gegee aan 'n definisie van die begrip kerk. Die doel daarvan is egter nie om ' $n$ uitgebreide definisie van die kerk se wese te formuleer nie, maar om aandag te gee aan 'n basisteorie waaraan die kerk herken kan word. So 'n herkenning is belangrik omdat die kerk in 'n veranderde wêreld funksioneer. Binne hierdie wêreld met sy uitdagings, probleme en behoeftes moet die kerk haar plek, rol en funksie verstaan en uitleef.

In die kleinste definieerbare vorm is die kerk die "saamgeroepte gemeenskap (koinonia) van gelowiges in Christus". So word dit bely in die Apostoliese Geloofsbelydenis (art. 10); Handelinge 2:47 leer ook dat die Here hulle wat tot geloof in Jesus Christus gekom het, by die gemeente "gevoeg het" (Oostenbrink \& Lotter, 1999:17). Berkhof (1994:555) wys op die Nuwe-Testamentiese gebruik van die woord ekklesia wat saam met sunagoge die woorde is waarmee na die kerk verwys word. Sunagoge word uitsluitlik gebruik om te verwys na die godsdienstige byeenkoms van die Jode, of die geboue waarin hulle bymekaar gekom het. Ekklesia verwys oor die algemeen na die kerk van die Nuwe Testament, alhoewel dit ook soms na openbare vergaderings verwys. Hiervolgens dra ekklesia die eenvoudige betekenis van "die saamgeroepte vergadering" met God as die "sameroeper". Heyns en Pieterse (1991:62) is van mening dat die wese van die "saamgeroepte vergadering" (of gemeente) goed beskryf word deur die term "liggaam". Volgens Duffield en Van Cleave (1987:419) is die kerk die goddelike ingestelde liggaam waardeur die evangelie uitgedra word en na gelowiges omgesien word. Dit wil voorkom asof daar breë konsensus bestaan dat die basisteoretiese beskrywing van die kerk rus op die pilare van "geroepe gemeenskap van gelowiges". "Geroepe" verwys na die goddelike handeling in die byeenbring van hierdie gemeenskap (vgl. Spoelstra, 1989:6). "Gemeenskap" verwys hier na saamgeroep wees, bymekaar wees, saam deel of meelewend wees. "Gelowiges" verwys na mense wat in 'n dienende, aanbiddende geloofsverhouding tot Jesus Christus staan.

Gemeenskap is in kerklike terme eerstens 'n skakeling tussen God en mens en daarna 'n skakeling tussen mense (vgl. Oostenbrink \& Lotter, 1999:75). In die onpersoonlike stadsituasie waarin al hoe meer mense hulself bevind, bied die gemeente as liggaam van Christus die ruimte vir innige persoonlike geloofsomgang met mekaar en met die Here. 
Dit is verder voor die hand liggend dat hierdie "gemeenskap" wat in 'n dienende verhouding tot Christus staan, nie sonder 'n doel bestaan nie. Vir Burger (1999:6) is die wêreldgerigtheid van die Christelike godsdiens, asook die verkondigde heil, 'n wesenlike deel van die gereformeerde geloof. Dit is vir Burger duidelik dat die kerk nie weggeroep word uit die wêreld nie, maar juis geroep word om op 'n nuwe manier in die wêreld te leef. Vir Luther en Calvyn was die roeping van die kerk en van Christene in die wêreld 'n belangrike saak (Burger, 1999:7). Nash (1997:88) sien as een van die primêre doelwitte van 'n kerk in enige era om 'n plek van ware gemeenskap te bied, en om daardie gemeenskap te ontwikkel op so 'n wyse dat dit die koninkryk van God vergestalt. Die "gemeenskap van gelowiges" bestaan uit persone wat eers nie deel was van hierdie gemeenskap nie, maar oortuig geraak het van die heerskappy van Christus en hulself dus in gehoorsaamheid skaar by die gemeenskap van gelowiges. Hulle het tot hierdie oortuiging gekom deur die werk van die Heilige Gees en die Woord, en blootstelling aan die getuienis van die liggaam van Christus aangaande die Christusgebeure.

Hierdie "getuienis" wat uitgaan van die kerk as gemeenskap van gelowiges is nie beperk tot Woordgetuienis nie, maar die apostel Jakobus maak dit in sy algemene sendbrief baie duidelik dat Woordgetuienis en daadgetuienis onlosmaaklik aan mekaar verbind is. Hierdie daadgetuienis het baie aspekte waarvan een die sosiale verantwoordelikheid van hierdie gemeenskap van gelowiges (die kerk) is. Jesus Christus het dit duidelik gestel dat die persone wat deel is van die "gemeenskap" soos sout vir die aarde, of soos 'n lig op 'n berg is (Matt. 5:13,14). Ander skrywers in die Nuwe Testament het ook klem gelê op die gelowige se sosiale verantwoordelikheid (vgl. Gal. 2:10). Die doel met die hierdie daadgetuienis is ook die eer van God (Matt. 5:16). Die gevolgtrekking is dat die kerk as "gemeenskap van gelowiges" bestaan met 'n sekere roeping om te vervul. Die geloofsomgang met God en mekaar moet so weerspieël word dat die kerk as "gemeenskap van gelowiges" ook na buite moet uitreik om mense in te trek: die kerk moet onder andere 'n sosiale verantwoordelikheid uitleef. Vervolgens word aandag gegee aan die omstandighede "buite" die kerk waarin die kerk geroep word.

\subsection{Die kerk en die wêreld vandag}

Die kerk bevind haar in 'n wêreld waar vryheid van denke, vryheid van spraak en menseregte belangrike uitgangspunte van die denkraamwerk vorm. De Klerk (1999:315) som die hedendaagse 
tendens op as weerstand teen die kerk, teen voorskriftelikheid, kerklike taal en lied, belydenis, prediking en kerklike betrokkenheid. Hendriks en Erasmus (2001:60) wys daarop dat die wyse waarop mense oor waarheid dink, drasties verander. Die pleidooi wat dus gelewer word, is dat die kerk dieper as styl sal moet sny. Ou waarhede sal nuut herdink, oor besin en geïnterpreteer moet word. Bo en behalwe laasgenoemde opmerkings is dit ook 'n werklikheid dat die meeste hoofstroomkerke tans 'n negatiewe groei in getalle toon (vgl. Van der Walt, 1999:1; Oostenbrink \& Lotter, 1999:13; Hendriks \& Erasmus, 2001:62). Oostenbrink en Lotter (1999:21) vind 'n rede vir hierdie verskynsel in die feit dat hedendaagse mense probleme ondervind om in die tradisionele kerklike opset hulle spiritualiteit uit te leef en Du Toit (2000:59) wys juis daarop dat die postmodernisme 'n nuwe soeke na die spirituele laat posvat het. Mense beleef die kerk egter as koud en die liefdevolle God as ver. Die rede hiervoor is dat hulle volledige mensheid, wat hulle sosiale en emosionele behoeftes insluit, nie altyd betrek word nie. Soos Louw (1998:18) tereg opmerk, moet die kerk ophou om te onderskei tussen kerk en samelewing en sal dit kerk in samelewing moet word (vgl. Burger, 1999).

Die eerste realiteit wat die kerk moet hanteer, is die verbrokkeling van die sosiale gemeenskap soos dit geken is. "Gemeenskap" verwys in hierdie verband na die sosiale bande wat tussen persone bestaan op die algemene vlak van familie en vriende en nie na die "gemeenskap van gelowiges" soos vroeër in die artikel gedefinieer nie. Nash (1997:88) wys daarop dat gemeenskappe in die modernistiese era baie maklik tot stand gekom het, omdat die kerk gebou was rondom families, woonbuurte en vriende. Almal het mekaar sosiaal geken en verstaan, en hulle het hierdie algemene gemeenskap in die kerk net voortgesit. In Suid-Afrika het wetgewing soos aparte woongebiede vir verskillende groepe hierdie homogene gemeenskappe help in stand hou. Strukturele veranderings in die Westerse wêreld en politieke veranderings in Suid-Afrika het egter ook in hierdie opsig noodgedwonge veranderings in die kerk teweeggebring.

Wat meer plattelandse gemeenskappe betref, het kinders die ouerhuise verlaat, gaan studeer en in stede gaan werk. In stedelike gemeenskappe moes albei ouers in baie gevalle begin werk om ekonomies te oorleef of om 'n gekose lewenstyl te handhaaf. Die gevolg was dus dat die natuurlike gemeenskapsbande nie meer so algemeen en op 'n sosiale wyse bestaan het nie. Kerke op die platteland moes diegene bedien wat agterbly, wat in vele gevalle die ouer of bejaarde mense was, asook jong kinders. Hierteenoor word 
stede weer gekenmerk deur baie enkellopendes wat uit uiteenlopende kontekste kom. Benewens hierdie verskynsel wat eie is aan 'n verstedelikingskultuur, bring die postmoderne kultuur ook nog 'n aantal gemeenskapsvraagstukke na vore. Cray (1998:11) wys daarop dat die postmoderne kultuur een is van tydelike gemeenskappe, baie ontmoetings, maar min verhoudings. Omdat identiteit 'n verbruikerskeuse geword het, kan die self dus kies saam met wie hy/sy wil sosialiseer. Hierdie nomadiese beweging van een gemeenskap na 'n ander word gevind in sekere gebeurtenisse soos 'n klubbyeenkoms, 'n fees, 'n protesmars, of 'n wedstryd. Die gemeentes van die hedendaagse tyd word dus gekenmerk deur 'n verbrokkelde sosiale gemeenskap.

Een van die vernaamste verskynsels van die postmoderne era is verder dat dit ' $n$ era van onsekerheid is. Cray (1998:12) wys daarop dat waar die belangrikste intellektuele vyand van die modernistiese tyd sekularisasie was, daardie rol in die postmodernisme ingeneem word deur relativisme. Daar word vandag geleef in die era van inligting. Mense word gebombardeer met inligting en met kompeterende aansprake op "die" waarheid, of die gebrek aan "'n" waarheid. Daar is geen oorkoepelende wêreldbeeld meer nie. Koerante, televisie en die radio is instrumente in hierdie algemene ontploffing en verbrokkeling van wêreldbeelde. Die media werk kompeterend, elk met 'n eie aanspraak tot waarheid, maar is ook skepties in die sin dat elke sodanige aanspraak betwyfel kan word. Die onsekerheid het verskeie negatiewe gevolge. Volgens Cray (1998:16) betaal jongmense die prys vir onsekerheid deur middel van hul liggame en persoonlikhede. Sake soos vrees, depressie, eetprobleme, selfmoord en ander selfvernietigende tendense begin toeneem. Tereg som die sanggroep U2 dié tendens in hul lied "Zooropa" met die volgende woorde op: "And I have no compass, and I have no map, and I have no reason, no reason to get back. And I have no religion, and I don't know what's what, and I don't know the limit, the limit of what we got" (U2, 1993).

Vir die postmoderne wêreldbeeld is die wyse waarop verbruik word, 'n belangrike element in die tipe identiteit wat 'n persoon aanneem. Die winkelsentrum het die gemeenskapsentrum geword waar mense mekaar ontmoet en leef. Hierdie consumerism, wat sy oorsprong alreeds in die modernisme het, hou die subjektiewe belofte vir mense in dat produkte en dienste iets vir hulle gaan doen. Die begeerte na die "nuutste" word gedurig gestimuleer. Vir Sine (1999:23) is consumerism een van die primêre waardes van die huidige generasie. Vir Boeve (1999:30) word die postmoderne individu gedegradeer tot 'n consumer, 'n verbruiker, 'n aankoops- 
faktor in die mark. Vryheid word geïdentifiseer met die vermoë om te kan koop (Boeve, 1999:30). Cray (1998:5) wys dat die probleem met consumerism ekonomies van aard is en dat dit 'n kultuur van dissatisfaksie skep, in plaas van contentment, oftewel tevredenheid. Hierdie kultuur sluit spiritualiteit nie uit nie, maar plaas dit op die rak as een van 'n reeks verbruikersitems. Hierdie nuwe omgewing en kultuur waarbinne mense leef, het die emansipasie van die self as ' $n$ primêre faktor gestimuleer. 'n Persoon se wêreld draai rondom wat verbruik word en daarin vind hy/sy hulself. Dit lei weer daartoe dat persone ook 'n ervaring in hul godsdiens wil beleef. Daar moet iets gebeur met hulle by die kerk, anders is dit vervelig. Dit is duidelik nie die doel van die kerk om aan elkeen 'n "aangename ervaring" te gee nie, maar indien die postmoderne kultuur beter verstaan word, noodsaak dit tog 'n verskuiwing van wat beleef word as 'n leë gestruktureerde spiritualiteit na iets wat meer tasbaar is en as lewensveranderend ervaar kan word.

'n Groot deel van die energie van mense in 'n postmoderne wêreldbeeld word bestee aan die vraag: Wie is ek? Hulle werk om 'n persoonlike identiteit te ontwikkel. Wanneer hierdie identiteit ontwikkel is, begin postmoderne mense soek na daardie gemeenskapaffiliasies wat hulle persoonlike identiteit bevorder en tot hulle spreek (Nash, 1997:88). Wat gebeur by die organisasie, moet met "hom/haar" gebeur. Die gedagte het ontstaan dat organisasies mense moet dien en nie andersom nie. Die sleutelwoord wat kerke in gedagte moet hou, is "keuse". Die postmoderne mens het 'n keuse, en hy of sy beoefen hierdie vryheid om te kies. Gedurende die tydperk van die modernisme is identiteit gevind in progressie, 'n ideologiese hoop op die toekoms. Die postmodernisme het hierdie sekerheid oor die toekoms verloor. In die postmoderne wêreld lê identiteit in die vermoë om 'n bepaalde narratief vir jouself te vind. Die individu se biografie moet aanhoudend eksterne faktore in sy/haar lewe integreer en binne die deurlopende storie van die "self" uitwerk (Cray, 1998:7). Waar identiteit gedurende die era van die modernisme geneig het om rondom 'n funksie en posisie in die openbare arena te draai, is die neiging in die postmodernisme na die ervaring van lewe, hoe ek lyk en wat ek verbruik. Die vraag na identiteit staan sentraal tot pastorale kerklike bediening omdat identiteit inherent 'n vraag na selfwaarde en selfbeeld impliseer.

Daar is reeds verwys na die geweldige geestelike ontwaking wat in die Westerse wêreld aan die ontwikkel is (Nash, 1997:49). Hierdie ontwaking vind egter in vele gevalle buite die grense van die kerk plaas. Die postmoderne era het 'n geestelike honger begin vermeng met ' $n$ wantroue in outoritêre instellings, insluitend godsdienstige 
instellings. Spiritualiteit is terug in die openbare omgewing, maar sonder rigtingwysers (Cray, 1998:13). Chris Carter, die skepper van die X-files, sê die volgende van homself: "I'm a non-religious person looking for a religious experience" (Cray, 1998:13). Hierdie stelling som die gees van die tyd goed op. Tog, in hierdie tyd van geestelike honger rig mense hulself tot spirituele boeke en ander geestelike middele, maar nie noodwendig tot die Bybel of die kerk nie. Die kerk as instituut word afgeskryf, omdat dit lyk asof die kerk nog in 'n premoderne of hoogtens modernistiese era vasgevang is.

In hierdie afdeling is gewys op 'n paar aspekte wat verband hou met sowel verstedeliking as postmodernisme as verskynsels. Alhoewel hierdie aspekte soms oorvleuel, is gepoog om aan te toon watter aspekte verband hou met elk van die twee verskynsels. As gevolg van hierdie verwikkelings is daar veral twee uitdagings vir die kerk wat uitkristalliseer. Die eerste kan beskryf word as mense se geestelike honger. Die tweede uitdaging is dié van geestelike vitaliteit. Geestelike vitaliteit word benodig om die veranderinge van die wêreld waarbinne beweeg word, te kan hanteer. Postmoderne mense soek 'n verhouding met God wat dinamies en lewensveranderend is. Tereg wys Oostenbrink en Lotter (1999:13) daarop dat gemeentes te staan kom voor 'n groot golf van verandering. As die golf teëgestaan word, kan dit die gemeentes plat slaan, maar as die energie van die golf reg gebruik en bestuur word, kan dit nuwe groei vir gemeentes meebring. Vervolgens word daarom spesifiek gefokus op die kerk in die postmoderne stedelike omgewing.

\subsection{Die kerk in 'n postmoderne stedelike omgewing}

Die probleem wat in hierdie afdeling aan die orde kom, is hoe die kerk as "gemeenskap" moet reageer ten opsigte van die verstedelikings- en postmoderne prosesse in die bereiking van die missie wat saamkom in aanbidding, uitreiking, diens en versorging insluit. Sweet (1999:2) maak die opmerking dat die kerk met betrekking tot hierdie veranderinge ook die toekoms in die oë moet begin kyk, en ophou om diegene wat dit wel doen, met misnoeë te bejeën. Vorster (1993:523) is van mening dat "kerkvernuwing" een van die belangrikste temas in die moderne ekklesiologie is. Shawchuck en Heuser (1993:167) stel dat die enigste gemeentes wat in die komende dekades sal oorleef, daardie gemeentes is waar die leiers geleer het om verandering te hanteer en nie te ignoreer nie. Tog kan die kerk nie (op heel modernistiese wyse) net aanpas by die mens, asof die mens in die sentrum staan nie. Die kerk moet in enige aanpassing wat gemaak word, steeds getrou bly aan haar goddelike roeping en eie aard, soos dit vroeër in die artikel 
benadruk is (vgl. 3.2). Daarom moet met omsigtigheid te werk gegaan word om te voorkom dat dit klink asof die kerk 'n organisasie is wat "'n nuwe lagie verf" moet kry vir 'n nuwe tyd, soos (om 'n heel profane voorbeeld te gebruik) nuwe rugbyreëls "die spel moet laat vloei ter wille van die skare". In so 'n geval sal die kern van kerkwees, naamlik die saamgeroepte gemeenskap met God as sameroeper, gemis word. Soos Van der Walt (1999:54) tereg uitwys, mag die kerk nie self postmodernisties word nie, maar moet dit wel die postmoderne mens bedien.

Tog is dit ook waar dat die kerk nie mag stagneer nie. Omdat die mense wat tot die "gemeenskap" toetree, uit bepaalde kulturele en sosiale kontekste kom, sal dit noodwendig ook 'n invloed hê op hoe die "gemeenskap van gelowiges" in praktyk daar uitsien. Soos wat tye, kontekste en wêreldfilosofieë verander, sal dit ook die samestelling van die "gemeenskap" beïnvloed. Dus is dit noodsaaklik vir die kerk om te poog om op "n wyse wat vir die hedendaagse mens verstaanbaar en effektief is, "gemeenskap" of kerk te wees. Dit help nie om steeds Grieks te praat as Engels die wêreldtaal geword het nie. Wat verander het, is nie die feit dat mense kommunikeer nie, maar wel die middele en metodes wat mense gebruik om hulself uit te druk en met mekaar te kommunikeer. Daarom juis dat die kerk nooit dit mag inboet wat haar sentrale wese is nie, maar dat wel na nuwe middele oftewel verpakking gekyk kan word, is voor die hand liggend (Burger, 2000:4). Dit sou middele wees wat die kerk kan gebruik om haar ware tradisionele boodskap uit te dra na 'n veranderde postmoderne stedelike wêreld. Richards (1970:39) maak die stelling (in die sewentigerjare alreeds) dat daar al meer 'n bewustheid kom dat die kerk nie langer met geboue, organisasies en aktiwiteite geïdentifiseer kan word nie, maar verstaan moet word as die "mense van God".

Prins (1997:38) wys daarop dat daar 'n duidelike verskuiwing is in die betekenis van rasionaliteit vir die huidige generasie teenoor dit wat vorige generasies daaronder verstaan het. Teenoor die idee dat die menslike rede die enigste manier is waarop kennis en insig verwerf kan word, word binne 'n postmoderne denkraamwerk aanvaar dat daar 'n behoefte aan 'n breër "rasionaliteit" is. Dit lei tot 'n herevaluering van dimensies van ken en verstaan soos uitgedruk in die metafoor, die mite, teken, verbeelding, simbool en ritueel. Prins (1997:38) kom tot die gevolgtrekking dat in die aanbieding van die evangelie aan die postmoderne generasie aandag gegee moet word aan die benutting van modi soos musiek en sang, simbool en ritueel, die narratief, drama en meditasie. In die maak van keuses vind die postmoderne mens hom/haar nie meer gebonde aan die tradisies, 
strukture en gebruike van die vorige geslag nie. Die diversiteit in opsies wat aangebied word, speel 'n groter rol (Prins, 1997:40). Volgens Du Toit (2000:65) is swart en wit denke nie meer moontlik nie. Daar is te veel "grys" gebiede om sonder meer absolute en finale aannames te maak. Beukes (1996:5) sluit hierby aan deur daarop te wys dat dit deel is van die postmoderne denke dat eenvormigheid binne groepe besig is om plek te maak vir diversiteit. Daarom dat daar 'n afkeer is van die outokratiese, "van-bo-af"kommunikasie van die evangelie. Ruimte sal gevind moet word vir 'n wyse van dialogiese kommunikasie. Dit wat die kerk aanbied, moet toon dat die stedelike postmoderne mens se vryheid tot keuse gerespekteer word.

Binne die postmodernisme het spiritualiteit 'n nuwe golf geword (Du Toit, 2000:59). Die rede hiervoor is dat die mens ontdek het dat hy/sy nie in 'n verstandelik verklaarbare wêreld leef nie. Die waarheid kan van vele kante af beskou word. Die absolutisme van die modernistiese era het plek gemaak vir diverse spiritualiteit. Daar is 'n verset teen die mag van die rede, wetenskap en tegnologie. Hierdie verset laat weer die eg menslike eienskappe van ervaring, gevoel en die betekenis van die individu na vore tree (Smit \& Vorster, 2000:519). Volgens Hendriks (1999:19) kies gelowiges vandag 'n kerk wat hulle geestelik, emosioneel en moreel rugsteun. Gelowiges se keuse val op lewende geloofsgemeenskappe wat mense verstaan en ook teologies bemagtig met die oog op die vrae en probleme van vandag.

Prins (1997:40) wys verder daarop dat die postmoderne era se sin vir individualiteit verander het in vergelyking met dié in die modernistiese era. Gedurende die tydperk van die modernisme het eiebelang en die bereiking van eie doelwitte altyd vooropgestaan. Die postmodernisme is minder produkgerig, en meer prosesgerig. Wat van belang is, is nie soseer die resultate wat bereik word nie, maar eerder hoe die proses verloop (Du Toit, 2000:67). Hieruit vloei voort dat persoonlike ambisie en doelwitte nie meer vooropstaan nie. Die aanvaarding van tradisie, strukture of waarhede is nie meer belangrik nie, maar eerder die aanvaarding deur ander binneverhoudings. Hiermee saam wys Beukes (1996:5) daarop dat daar in die kerk ' $n$ beweging is waar hiërargie met gelykheid vervang word. Outoritêre, strak bediening is besig om plek te maak vir 'n meer informele vorm van bediening. Die gemeente word nie meer gesien as die objek van bediening nie, maar as medesubjek. Daar word al meer aanvaar dat die gemeente se funksionering soos ' $n$ lewende organisme is wat uit prosesse bestaan en nie uit programme nie. Dit het verder tot gevolg dat daar nou meer met ' $n$ 
"gemeenskaplike liggaam van Christus"-model gewerk word as met 'n "herder-kudde"- model.

In die lig van bogenoemde sake word die tweede deel van hierdie artikel vervolgens gewy aan praktykgerigte voorstelle oor kerklike bediening.

\section{Voorstelle vir kerklike bediening in die huidige konteks}

Die voorstelle wat in hierdie afdeling aan die hand gedoen word, raak eers kerklike bediening in die algemeen aan, waarna die aandag bepaal word by enkele konkrete gedagtes oor die erediens en pastorale sorg.

\subsection{Vernuwingsingesteldheid}

Die eerste prioriteit waaraan alle kerkleiers en gelowiges sal moet werk, is 'n vernuwingsingesteldheid (Ef. 4:23). Met vernuwing word verwys na ' $n$ ingeligte verstaan van eerstens die filosofiese grondslag van die tye waarbinne die kerk tans funksioneer, dit wil sê 'n verstaan van die oorgang vanaf die modernisme na die postmodernisme en die implikasies wat dit het op die samelewing. Tweedens moet daar 'n ingeligte verstaan wees van die veranderde demografie van ons samelewing. ' $n$ Verandering in demografie sluit die volgende in: die verskuiwing vanaf die platteland na die stad en die veranderinge wat daarmee gepaardgaan, en die verandering en verbrokkeling van gesinsverbande en tradisionele sosiale gemeenskapsbande.

Verder word met vernuwing verwys na 'n openheid vir diversiteit en andersheid binne eie geledere. Volgens Hendriks (1997:35) is die hantering van diversiteit en pluralisme een van die grootste uitdagings vir die kerk in Suid-Afrika. Burger (1999:4) wys daarop dat kerke moet besef dat tradisie nie genoeg is nie. Om die toekoms dinamies en relevant tegemoet te gaan, sal hulle weer 'n geestelike vitaliteit moet ontwikkel. Binne hierdie konteks in Westerse lande is Nash (1997:38) van mening dat die kerk 'n nuwe strategie sal moet daarstel. Dit sal behels dat die kerk in dialoog betrokke moet raak met 'n postmoderne stedelike wêreld. Ook impliseer dit 'n poging om mense en hul realiteite te verstaan in plaas daarvan om gedurig tradisionele antwoorde en oplossings te probeer gee. Die klem val dus meer op versorging as op oplossings, meer op empatie as op raadgee en uiteindelik op 'n dieper intimiteit met God as bloot die lidmaatskap van 'n denominasie. 


\subsection{Spiritualiteit}

Daar is reeds verwys na die geestelike ontwaking wat in die Westerse wêreld aan die ontwikkel is (Nash, 1997:49). Volgens Smit en Vorster (2000:521) dryf die postmoderne gemeenskappe los van godsdiensankers, maar erken tog 'n behoefte aan spiritualiteit op 'n groter verskeidenheid maniere. McGrath (1999:9) definieer spiritualiteit as die poging om ' $n$ mens se geloof in verband te bring met "a very specific set of personal and institutional factors" en wys dan daarop dat die konteks waarin 'n individu hom/haar bevind, 'n rol speel in die uitlewing van die Christelike geloof (McGrath, 1999:12). Wat hierbo rondom verstedeliking en die postmodernisme oor die algemeen opgemerk is (vgl. 2.1 en 2.2), sal dus ook 'n invloed uitoefen op 'n individu se spiritualiteit.

Die feit dat mense geestelik honger is, hou geleenthede in vir die bediening van die kerk, omdat daar wyses gevind kan word om die geestelike honger te stil deur die evangelie effektief te kommunikeer. 'n Probleem ontstaan omdat Westerse kerke nie die geestelike vitaliteit het om die oorgang van die modernisme na die postmodernisme te hanteer nie, en verder is ' $n$ tendens van verset teen verandering ook aanwesig. Om 'n postmoderne generasie egter in die kerk te behou of na die kerk te lok moet 'n geestelike lewendigheid in die kerk teenwoordig wees (Burger, 2000:4). Hierdie geestelike lewendigheid mag verskil van denominasies en gemeentes (McGrath, 1999:13-14). Du Toit (2000:175) wys daarop dat elke persoon se spiritualiteit nóú saamhang met sy/haar persoonlikheidsbehoeftes en daarom is dit belangrik dat verskillende spiritualiteitsmodelle van mekaar moet leer, om sodoende elke persoon toe te laat om sy/haar eie spirituele tuiste te vind waar geloof in God vir hulle sin maak en God 'n werklikheid in hulle lewens is.

Die lewensfilosofie van 'n generasie wat groot word binne die stedelike omgewing en postmoderne denkraamwerk verskil van 'n lewensfilosofie wat uit 'n modernistiese era kom. Vele kerke is egter steeds sterk gebou op 'n modernistiese lewensfilosofie waar gesag, harde werk, beloning en strukture van belang is. Nuwe denke begin by 'n beter verstaan van spiritualiteit vir die individu. Vir Burger (2000:4) beteken dit dat die kerk weer sal moet kyk na kerklike tradisies, kulture, strukture, liturgiese vorms, reëls, en voorskrifte spesifiek of dit deur die Bybel voorgeskryf word. Vir Smit en Vorster (2000:521) lê die kern van die geestelike antwoord ook by wat die kerk (GKSA) met God en sy Woord gaan maak. Omgang met die Woord kan nie slegs 'n vervlakte menslike aktiwiteit wees wat binne 
die erediens "afgehandel" moet word nie. Weereens is dit 'n kwessie van metode of wyse, maar sonder om diepte en substansie te verloor. Dat God en sy Woord as vertrekpunte vir 'n geestelike ervaring moet dien, is nie te betwyfel nie. Hoe dit egter sal geskied, is belangrik. Vir 'n generasie wat absolutisme verwerp, is ' $n$ outoritêre eenrigtinggesprek in die erediens van min waarde. Wat wel van belang vir hierdie kultuur is, is om deel te kan hê aan die gesprek, om deur 'n kommunikerende wisselwerking in waarheid te groei (Ef. 4:16). Die persoon sal deur die gesprek en die ervaring (Kol. 3:16) daaraan gekoppel, die waarheid integreer en as verhoudingsdraers die absolute in hul lewens uitleef.

Geloofsrelevansie vir die gemeenskap beteken nie die prysgee van geloofsbeginsels nie, maar juis 'n nuwe waardering daarvan en die vermoë om dit in die gemeenskap relevant te maak. Daarom dat daar gedurende die laaste aantal jare so 'n groot klem gelê is op kleingroepbediening of selbediening binne gemeenteverband. Vir Beukes (1999:3) is een van die gevolge van die postmodernisme die feit dat mense vra na 'n verdiepte spiritualiteit asook verdiepte onderlinge menslike verhoudings. Hy wys daarop dat baie van die eerste Christelike byeenkomste in huise plaasgevind het (Hand. $2: 46$ en 12:12). Die huisgroep of selgroep is 'n sterk skakelpunt vir die postmoderne generasie. In die stedelike konteks waar "individualisering en vereensaming" maklik kan voorkom, bied dit wat Pieterse (2002:94) omskryf as groepsbediening, 'n antwoord daarop.

Daar sal 'n klemverskuiwing moet kom van 'n oormaat gefragmenteerde kerklike aktiwiteite na die verfyning van 'n meer gefokusde binnekamerverhouding met God as bron vir spiritualiteit. Hierdie binnekamerverhouding moet dan tot uiting kom in die bou van verhoudings binne kleiner, intiemer verhoudingsgroepe (vgl. McGrath [1999:8-19] vir die verband tussen persoonlike sake en denominasionele oorwegings in die vorming van spiritualiteit). Dit sal help om die geleenthede te ontdek wat nuwe ontwikkelings aan die bediening bied ten opsigte van die vestiging van gesonde verhoudinge. Wat vir Prins (1997:38) van deurslaggewende betekenis is, is dat die mense in betekenisvolle verhoudings ongeag ouderdomsgroepering - betrokke sal raak. Binne sulke verhoudings moet die realiteit van God se genade in Christus in woorde en dade gesien en ervaar kan word. Dit sal verhoudings binne gesinsverband, huwelike, vriendskappe en selfs werksverhoudinge raak. Van der Walt (1999:3) wys egter daarop dat die kerk versigtig moet wees om kleingroepe as 'n wondermedisyne vir alle kwale te probeer sien, sonder om die werklike probleem te 
behandel. Hierdie probleem lê vir hom op die vlak van die roeping wat die kerk het en wat vervul moet word. In baie gevalle is dit duidelik dat die verandering na slegs kleingroepbediening in 'n gemeente nie die oplossing is om kerkwees relevant te maak nie. Kleingroepbediening word in baie gevalle gebruik as 'n dekmantel vir predikante wat verkies om nie meer werklik betrokke te wees by gemeentelewe nie, maar net Sondae vanaf 'n hoë kansel die lidmate wat hulself in kleingroepe moet voed, wil "toespreek" (vgl. Oostenbrink \& Lotter, 1999:80). Daar sal volgens Van der Walt (1999:3) dieper gesny moet word as net 'n blote herstrukturering van die gemeente. Postmoderne mense soek 'n verhouding met God wat dinamies en lewensveranderend is, en wat verder lei tot gesonde lewensverhoudings.

\subsection{Postmoderne identiteit}

Cray (1998:20) wys op die belang daarvan dat die ervaringswêreld van hedendaagse mense, met spesifieke verwysing na die jeug, totaal anders is as wat dit tradisioneel was. Daar is die tendens dat ouer mense dink dat jonger mense deur dieselfde lewensfases en -omstandighede moet werk as dié wat die ouer mense self ervaar het. Dit is algemeen bekend dat die voorkoms van generasiegapings geen nuutjie is nie, en dit is ook so dat sowel ouer as jonger mense deur die postmoderne en verstedelikingsprosesse geraak word. Tog het postmoderne tendense die wêreld drasties verander en veral die spoed van verandering veroorsaak dat die gaping tussen generasies drasties toeneem. Dikwels vind hierdie verandering in stedelike gebiede vinniger plaas vanweë beter infrastrukture en kommunikasiekanale. Elke paar jaar is daar 'n generasie wat die wêreld totaal anders ervaar as hulle resente voorgangers. Die kerk as "geroepe gemeenskap van gelowiges" sal moet aanvaar dat hierdie vreemde wêreld wat ontwikkel, nie so vreemd vir God is nie. Sy liefde, teenwoordigheid, betrokkenheid en vrede transendeer alle tye en kulture en is veral van toepassing in die hede. In hierdie konteks kan 'n teoloog soos Moltmann (1988:39) se gedagte van 'n teologie van hoop wat te make het met die gedurige volwassewording (groei) en ontwikkelende "beeld" van Christus, wat die "beeld" van ware menswees is, geherinterpreteer word. Hoop en belofte nooi die postmoderne self vanuit die toekoms uit om 'n gerekonstrueerde identiteit te ontdek. Die beeld van Jesus is die kontrolerende model waarvolgens God en self geïnterpreteer kan word (Thiselton, 1995:163).

Thiselton (1995:121) is oortuig dat weens die ineenstorting van selfidentiteit in die modernistiese era, daar 'n behoefte aan so 'n 
teologie van hoop is. Vir Smit en Vorster (2000:522) is een van die uitdagings vir die kerk die volgende: "Hoe om vir mense wat alles wat stukkend is, weggooi, die Heelmaker te bring". Hulle is van oortuiging dat die kerk die suiwer leer van die Woord van God moet beoefen. Cray (1998:20) wys daarop dat die kultuur van gebroke identiteit en een waar identiteit bepaal word deur consumerism en die algemene mode, juis een is wat as objek vir God se liefde dien. Daarom dat die kerk ' $n$ instrument moet wees van hoop, liefde en aanvaarding van ' $n$ gebroke wêreld met 'n gebroke, wisselvallige identiteit. In 'n postmoderne, stedelike omgewing sal so 'n "hoop" oorgedra moet word in die bediening van die kerk deur sorg, liefdevolle verhoudings en die verblydende goeie nuus van die Jesus Christus-narratief. Verder sal ook gekyk moet word na meer bruikbare tipes uitreiking en verkondiging, veral binne stedelike gebiede. Hierdie tipe uitreiking sluit in armsorg, voedingskemas, mediese hulp, ontwikkelingsmoontlikhede en vele meer. Volgens Smit (2001:14) moet die kerk as vennoot in die samelewing optree en mense help om hulself te kan help. Verder kan die kerk sy boodskap begin uitdra op ander wyses as net deur middel van prediking en deur te onthou dat die huidige wêreld een is wat gewoond is aan kleur, spoed en energie. Daarom kan aktiwiteite soos dramas, teaterstukke, musiekopvoerings en multimediaaanbiedings ontwikkel word om die boodskap van hoop uit te dra. Dit skep die geleentheid van ware organisme wees deurdat Christene sodoende die geleentheid kry om op 'n wyse waarmee hulle bekend is, hul getuienis uit te leef.

Cray (1998:22) sluit aan by die belang van die uitlewing van 'n bepaalde identiteit in Christus in 'n postmoderne leefwêreld. Hy verwys na Galasiërs $5 \mathrm{om}$ aan te toon dat gelowiges nie vry is om enigiets te doen met hulle lewe en wêreld nie, omdat hulle vir 'n spesifieke doel geskape is. Om te weet wie ons is, moet ons verantwoordelik wees teenoor die Een wat ons geskape het. In 'n wêreld van onsekerheid is dit belangrik om seker te wees van verlossing en in 'n vaste verhouding met die Verlosser te staan. Draper (2001:8) sluit aan by Johannes 1 en 3:16 deur daarop te wys dat Jesus Christus die gawe van lewe gebring het. Vir Draper $(2001: 8)$ is dit van besondere belang met die oog op identiteit. In 'n tyd waar identiteit op die spel is, is daar 'n geleentheid om in Christus te ontdek wat dit beteken om te lewe. Christene wat in gehoorsaamheid aan Christus wil leef, moet daarop gewys word hoe om te onderskei tussen die skep van 'n nuwe identiteit en om jouself te beklee met Christus. In 'n tyd waar 'n sogenaamde image baie belangrik is, kan die vraag gevra word na wat dit beteken om na die 
beeld van Christus geskape te wees. Weereens word dit duidelik dat die intieme binnekamerverhouding met God in hierdie tyd net so belangrik is as in enige ander tyd, en dat die fokus van die "gemeenskap van gelowiges" hiertoe sal moet skuif, eerder as organisatoriese en outoritêre kerkstrukture en -programme. Die krag van consumerism lê in die belofte dat dit vervulling in die teenswoordige kan bied, terwyl die toekoms onseker lyk. Pastorale sorg sal moet fokus op die hoop van 'n toekoms wat die moeite werd is om voor te leef. 'n Visie van God se toekoms en ons betrokkenheid daarin moet vasgelê word. Cray (1998:23) benadruk dat een aspek waaraan die gemeenskap van gelowiges aandag kan gee, die aktiewe bediening aan die armes is, omdat die kultuur van consumerism die arme uitsluit. Verder is een van die eienskappe of vrugte van dissipelskap dankbaarheid of tevredenheid. Hierdie tevredenheid word gebou op die fondament van vertroue in God wat betrokke is in my lewe, my behoeftes ken en verstaan, en ook weet wat en wanneer genoeg vir my genoeg is (Fil. 4:6).

Een van die kenmerke van die postmoderne mens is sy/haar verstaan van keuse en identiteit. Die voordeel van die postmoderne "keuse-sindroom" is dat die kerk 'n geleentheid het om die koninkryk van God te weerspieël juis omdat gemeenskap nie op 'n silwer skinkbord ontvang word nie. Hedendaagse gelowiges besluit om in te skakel by hierdie gemeenskap op grond van hul eie oortuiging, en nie omdat hulle daarin gebore is, of deur die samelewing daarin "gedruk" is nie. Hierdie tipe gemeenskap kan 'n Christus-gesentreerde gemeenskap wees as almal wat daaraan deel het, besluit om hulle identiteit in Christus te anker deur 'n Christus-gesentreerde lewe te lei.

\subsection{Bereikbare kerkwees}

Smit en Vorster (2000:522) vra hoe om vir 'n samelewing wat gewoond is aan vervanging en inruiling, die Onvervangbare aan te bied. Vir Nash (1997:84) lê dit in die sigbaarheid van die kerk binne die hedendaagse wêreld. Sigbaarheid is iets wat mense sal trek. Teoreties is sigbaarheid ook iets wat mense kan afstoot, maar dit beteken nie dat die kerk eerder onsigbaar moet wees nie. Sigbaar beteken in hierdie konteks bereikbaar. Postmoderne, stedelike mense is gewoond aan 'n wêreld waar alles vinnig en maklik bereikbaar is - vanaf vinnige vervoersisteme, verbysterende kommunikasiefasiliteite tot vinnige kos (MacDonald's). Die kerk en die mense daarbinne moet bereikbaar wees vir ongelowiges wat daar gaan soek vir hulp. Met sigbaar word word bedoel dat die kerk, plaaslik en universeel (Du Plooy, 1979:26), so moet wees dat 
mense dit kan sien, kan hoor en ervaar - nie soseer as 'n gebou met 'n hoë toring op die hoek van die straat nie, maar eerder as 'n lewende organisme of gemeenskap wat in hierdie wêreld leef en so in 'n dienende verhouding tot God staan dat ander mense daardeur geraak en ingetrek word by die gemeenskap. Vir Oostenbrink en Lotter (1999:17) moet die kerk in die wêreld uitkenbaar wees aan die liefdevolle verhoudings binne die gemeenskap van gelowiges. Duidelik stel Jesus Christus dit in Johannes 13:35 dat as gelowiges mekaar liefhet, sal die wêreld weet dat hulle sy dissipels is.

Tereg wys Van der Walt (1999:12) daarop dat om 'n lidmaat van die kerk te wees ingrypende konsekwensies het vir 'n persoon se lewe deur sekere eise van dissipelskap te stel. Kerkmense leef vanuit 'n Goddelike opdrag en roeping en moet bereid wees om 'n getuienis uit te leef wat sigbaar is in hierdie wêreld. Baker (1999:45) wys daarop dat in die postmoderne kultuur baie ruimte bestaan vir sigbaarheid. Die kerk kan sigbaar raak deur haar "storie" van die evangelie te vertel; die "narratief" van redding wat te vinde is in Jesus Christus; die "storie" van 'n Vader wat sy Seun gegee het sodat ander kan lewe; die "narratief" van 'n intieme verhouding met die Vader en sy Seun deur sy Gees wat Hy ons gegee het, en die "narratief" van hoop op verlossing en 'n nuwe en beter wêreld wat kom. Dit sal nie die enigste storie wees wat vertel word nie, maar indien ons storie substansie het, kan dit goed gekommunikeer word aan die hoorders. Baker (1999:36) merk in hierdie verband op: "Signs, symbols, images, ritual, drama, stories and expierence these are all part of the discourse or language of our culture. We can read and interpret them. A good telling of a story will catch our imagination ..."

Deur Christene wat hul Christelike storie daagliks leef - 'n storie wat wentel om die Christusgebeure - kan die kerk haar sigbaarheid en bereikbaarheid in hierdie wêreld vergroot. Die storie wat hierdie Christusgebeure in mense se lewe wil vergestalt, het as inhoud die redding, verlossing, oorwinning en 'n intieme verhouding met God. Die Heilige Gees is die Gestuurde Persoon wat dit vergestalt in die gelowige. Hy is immers die een volgens Johannes 14-16 wat sal oortuig van sonde, wat as Trooster en Helper sal optree, en wat die gelowiges in die volle waarheid sal lei.

Die vraag kan gevra word of dit nie te moeilik is vir Christene om na hulle Christenskap te kyk as iets wat sigbaar moet wees in die wêreld nie? Die antwoord is dat Christenskap nie oor gemak gaan nie, maar oor 'n kruis. Dit gaan oor 'n kwaliteitverhouding met God asook met medegelowiges en as getuies in die wêreld (Oostenbrink 
\& Lotter, 1999:6). Een rede waarom die kerk haar geestelike vitaliteit kon verloor het, is juis omdat gemak en status in plaas van relevansie en diensvaardigheid een van die oogmerke geword het. Volgens Hendriks (1997:29) sal lidmaatskapverlies nie bekamp word deur beter programme nie, maar slegs met 'n herontdekking van identiteit, wat gefundeer is in Christus. In hierdie era sal die kerk moet ag gee daarop dat alles wat gedoen word, gegrond moet wees in die Christusgebeure soos gevind in die Bybel. Alles wat gedoen word, word gedoen vanuit die begronding van vrywillige onderwerping aan die heerskappy van Jesus Christus. Hendriks stel dit duidelik (1997:29) dat die gelowige wat geestelik gaan oorleef, een is wat 'n betrokke, roepingsbewuste lidmaat is; iemand wat as Christen getuig en dien by kerklike en sekulêre geleenthede. Om hierdie rede moet die kerk in 'n postmoderne, stedelike omgewing duidelik die roeping van Jesus Christus tot diensbaarheid, dissipelskap en selfverloëning verstaan. Dit sal weer 'n kerk, wat sigbaar as liggaam van Christus in hierdie wêreld funksioneer, tot gevolg hê (Nash, 1997:84).

\subsection{Onderlinge sorg}

Tradisioneel was pastorale sorg gemik op gelowiges binne gemeentelike strukture en diegene buite die strukture was 'n objek van sending of evangelisasie. Cray (1998:19) wys daarop dat pastorale bediening in die nuwe kulturele omgewing moontlik die belangrikste vorm van evangelisasie en sending geword het. Vergelyk die verhouding waarin God se liefde en "die wêreld" in Johannes 3:16 geplaas word. Daarom dat dit dikwels voorkom asof die advies wat aan die kerk gegee word vir omgaan met 'n wêreld wat verander het, tegelykertyd geld vir die bediening aan gelowiges en ongelowiges. Dit blyk dat pastorale en kerklike bediening meestal buite die grense van die tradisionele kerkstrukture begin plaasvind in 'n omgewing waar gelowiges en nie-gelowiges langs mekaar lewe, soos byvoorbeeld in skole en ander opvoedkundige instansies. Dit is asof die bedieningsveld verskuif het van die tradisioneel kerklike programme na bediening in openbare ruimtes. In 'n land soos SuidAfrika het daar saam met die politieke oorgang van oud na nuut ook ' $n$ aantal godsdienstige veranderings ingetree. Die meeste skole het nie meer, soos vroeër, Bybelonderrig as vak nie en Christelikgeoriënteerde hoofde is toenemend besig om predikante en jeugwerkers te betrek om die geestelike bediening van kinders in skole te behartig deur spesiale sessies, dienste, praatjies, berading, gebed en ander vorme. Die aanbieding van kampe speel ook 'n groot rol indien geestelike bediening in skole deur die owerhede 
gestaak gaan word. Verder is daar 'n wye verskeidenheid groeperings in die samelewing wat spontaan ontstaan sonder vaste strukture waar bediening ook al meer in openbare arenas ingedra word - byvoorbeeld vrouegebedsgroepe, besigheidslui wat saam Bybelstudie hou, gebedsgroepe in etenstye by groter nywerhede en vele meer. Dit het juis die wyse geword om gelowiges hier te versterk, asook om ongelowiges in te trek deur pastorale sorg.

So 'n verandering van die fokus van pastorale sorg het noodwendig ook 'n invloed op die kerkgebou. Volgens Theron (1992:10) sal die kerksentrum in veral stedelike gebiede 'n nuwe rol moet vervul. Dit sal nie net meer 'n plek moet bied waar mense "bepreek" kan word nie, maar sal 'n tuiste moet wees waar al die lede van die gemeente betrokke kan raak in onderlinge verhoudings en om sorgend na andere uit te reik. Die sending- en evangelisasievelde is ook nie meer ver weg nie en lê nou binne die gemeentegrense. Daarom moet die kerkgebou aangepas word om voorsiening te maak, nie meer net vir die gemeente nie, maar ook vir die gemeenskap daarbuite. So 'n evangelisasieproses sal baie meer deur pastorale sorg en verhoudingbou in en rondom die kerkgebou moet geskied, as net deur 'n preek. Volgens Theron (1992:10) moet daar verskillende lokale beskikbaar wees vir eredienste, opleiding, opvoerings en seminare, sodat verskeie groepsaktiwiteite gelyktydig kan plaasvind. Vir Theron (1992:10) is die hoofsaak dat die kerkgebou nie meer as 'n kosbare kleinood vir die erediens alleen bewaar kan word nie. Alhoewel Theron reeds in die negentigerjare sy gevolgtrekkings gemaak het rondom kerklike geboue, word dit al meer van belang dat gemeentes tot hierdie besef sal kom. Saam met die postmoderne siening en ook die gebrek aan ruimte wat deur verstedeliking ontstaan, sal besef word dat kleiner beter kan wees. Intieme samekomste kan van meer belang word as groot massasamekomste soos eredienste. Verder kan die gemeentes baat vind deur meer gereelde kleiner eredienste te hou. In 'n postmoderne samelewing tel ervaring en verhouding meer as outoritêre eenrigtingprediking. Volgens Burger (2002:4) wil mense vandag die volgende weet: Werk dit?, Wat beteken dit vir my?, Kan ek dit beleef? Dus sal die kerk uit 'n konteks van pastorale sorg nuut moet dink oor die nodigheid van groot en duur ouditoriums en moet soek na meer praktiese effektiwiteit.

\section{Samevatting}

Dat die kerk sal moet vernuwe om (menslik gesproke) verseker te wees van haar voortbestaan is duidelik. Vernuwing loop hand aan hand met 'n duidelike deurgronding en verstaan van die prosesse 
van verstedeliking en postmodernisme, naamlik hoe hierdie prosesse teoreties funksioneer, maar nog meer hoe dit die mens in sy/haar daaglikse lewe beïnvloed. Dit is hier in die daaglikse lewe waar die kerk haar impak moet laat voel: op straat waar mense lewe as gewone individue, wat voel, wat ontnugter word, wat onseker is en wat die hoop wat Jesus Christus bring, nodig het.

Die postmodernisme en verstedeliking het reeds aanleiding gegee tot vele gesprekke en debatte wat bepaalde voordele inhou. Die spoed van die verandering is egter so snel dat die kerk dit minder kan bekostig om te debatteer oor hierdie verskynsels en eerder na 'n "doen"-fase moet oorskakel. Die blote feit dat daar 'n wêreldwye behoefte ontstaan het aan spirituele belewenis, pastorale sorg en 'n boodskap van hoop, is reeds 'n teken dat die kerk die oorgang na 'n postmoderne samelewing in 'n mate gemis het. Daar is dus reeds ' $n$ agterstand om in te haal. Wat dit nog meer beklemtoon, is die feit dat die media, advertensiewese, ekonomie, vermaaklikheidsbedryf, ensovoorts, reeds die veranderinge geïnkorporeer het in hul bedrywighede. Dit lyk soms asof die kerk die enigste entiteit is wat nog wonder of dit haar gaan raak en of sy daarop moet reageer. Die nuwe tydgees bring mee dat die Christelike eiesoortigheid en deursettingsvermoë, tesame met die kreatiewe leiding van die Heilige Gees, tot uiting moet kom.

Die kerk sal in hierdie tye 'n bewustheid van status, geboue, finansies en strukture moet verruil vir 'n besef dat daar weer na die basis van haar wese teruggekeer moet word. Dit sluit die besef in dat die kerk 'n "geroepe gemeenskap van gelowiges" is wat as organisme funksioneer. Dit beteken dat Christene en hulle leiers moet ophou wegkruip agter strukture en werklik sigbaar en bereikbaar binne 'n "veranderende" wêreld moet wees.

Die uitdagings van die hedendaagse tyd soos die verbrokkeling van die sosiale gemeenskap, die tendense van onsekerheid, consumerism, soeke na identiteit, godsdiens as kommoditeit, asook geestelike honger moet gehanteer word, en kan nie weggewens word nie. Die wyse waarop dit gehanteer moet word, kan verskil van gemeente tot gemeente en van gebied tot gebied. Daar is in 'n postmoderne wêreld nie een algemene resep vir effektiwiteit nie, maar indien daar biddend deur die Gees leiding ontvang word, getrou gebly word aan God se Woord, en die benaderingswyse van ervaring, intieme verhoudings, 'n Christus-identiteit en pastorale sorg toegepas word, tesame met 'n vryheid en openheid vir diversiteit, kan daar resultate wees. Jesus Christus het belowe dat 
Hy sy kerk sal bou, en dit sluit die kerk in 'n postmoderne stedelike wêreld in (Matt. 16:18 en 28:19, 20).

\section{Bibliografie}

ADAM, A.K.M. 1995. What is postmodern Biblical criticism? Minneapolis : Fortress.

BAKER, J. 1999. Rhythm of the masses. (In Ward, P.. ed. Mass culture. Eucharist and mission in a postmodern world. Oxford : The Bible Reading Fellowship. pp. 33-53.)

BAKKE, R. \& HART, J. 1987. The urban Christian: Effective ministry in today's urban world. Downers Grove : Intervarsity.

BERKHOF, L. 1994. Systematic theology. Bath : The Bath Press.

BEUKES, B. 1999. Kleingroepbediening. Die Hervormer, 92(17):3.

BEUKES, M.J. 1996. Gemeentebou. Die Hervormer, 89(10):5-8.

BOEVE, L. 1999. Market and religion in postmodern culture. Theology, 102(52):28-36.

BREYTENBACH, H.S. \& PIETERSE, H.J.C. 1992. Doelwitte vir gemeentebou in die lig van 'n Prakties-Teologiese ekklesiologie. Praktiese Teologie in S.A., 7(2):101-112.

BURGER, C. 1999. Erediens in gereformeerde styl. Praktiese Teologie in S.A., 14(1):1-22.

BURGER, I. 2000. Is die kerk nog ter sake vir die jeug? Die Kerkbode, 164(7):4.

BURGER, I. 2002. Nuwe Hervorming? - pure New Age. Die Kerkbode, 169(3):4.

CRAY, G. 1998. Postmodern culture and youth discipleship; commitment or looking cool? Cambridge : Grove Books.

DE KLERK, B.J. 1999. Vaartversnelling vra verdieping van ons liturgie. In die Skriflig, 33(3):311-331.

DRAPER, B. 2001. True to one self? EG, Reclaim the streets. Licc Resource, 6:8.

DUFFIELD, G.P. \& VAN CLEAVE, N.M. 1987. Foundations of Pentecostal theology. Los Angeles : L.I.F.E. Bible College.

DU PLOOY, A. LE R. 1979. Eklessia en meerdere vergaderinge. Potchefstroom : PU vir CHO. (Th.D.-proefskrif.)

DU TOIT, B. 2000. God? Geloof in 'n postmoderne tyd. Bloemfontein : CLFUitgewers.

FLESHMAN, M. 2001. Aids orphans: facing Africa's "silent crisis". Africa Recovery, 15(3):1.

FOURIE, L.C.H. 2000. Die invloed van die internet op ons lewenswyse. Woord en Daad, 40(373):14-16.

HEITINK, G. 1993. Praktische Theologie. Kampen : Kok.

HENDRIKS, H.J. 1997. Kerklike "megatrends": bedieningsimplikasies. Nederduitse Gereformeerde Teologiese Tydskrif, 38(1/2):27-38.

HENDRIKS, H.J. 1999. Gaan gereformeerde kerke groei, kwyn of verdwyn? Woord en Daad, 39(369):13-19.

HENDRIKS, H.J. \& ERASMUS, J. 2001. Interpreting the new religious landscape in post-apartheid South-Africa. Journal of Theology for Southern Africa, 109:41-65.

HEYNS, L.M. \& PIETERSE, H.J.C. 1991. Eerste treë in die Praktiese Teologie. Pretoria : Gnosis boeke. 
JANSE VAN RENSBURG, J. 2001. The paradigm shift. An introduction to postmodern thought and its implications for theology. Pretoria : Van Schaik.

JENKINS, J.W. 1997. Urbanisation and security in SA. African Security Review, 6(6):54-63.

KOK, P. \& GELDERBLOM, D. 1994. Urbanisation. South Africa's challenge. Volume 2. Pretoria : HRSC.

LOUW, D.J. 1998. Die konsep "Prakties-Teologiese spiritualiteit" binne 'n konteks van postmodernisme en globalisering. Praktiese Teologie in S.A., 13(2):16-25.

MCGRATH, A.E. 1999. Christian spirituality. An introduction. Oxford : Blackwell. MOLTMANN, J. 1988. Theology today. Freiburg : Herder.

NASH, R.N. 1997. An 8-track church in a CD world. Macon, Georgia : Smyth \& Helwys.

NAUDÉ, P. 1992. Bedieningspraktyk tussen modernisme en postmodernisme: perspektiewe vir 'n studentebediening. Nederduitse Gereformeerde Teologiese Tydskrif, 34(1):94-99.

NEUTJENS, C. 2000. Het Christendom in een postmodern perspectief. Koers, 65(3):281-340.

OLTHUIS, J. 1999. Dancing together in the wild spaces of love; postmodernism, psychotherapy and the spirit of God. Journal on Psychology and Theology, 16(2):140-152.

OOSTENBRINK, J. \& LOTTER, G. 1999. Die groot God by kleingroepe. Potchefstroom : DPM.

PIETERSE, H.J.C. 2002. Prediking in 'n postmoderne lewensgevoel. Praktiese Teologie in SA, 17(1):75-101.

PRINS, J.M.G. 1997. Postmoderniteit en jeugbediening - enkele aspekte van 'n paradigmaverskuiwing en die implikasies daarvan vir die kerklike jeugbediening. Praktiese Teologie in S.A., 12(2):38-46.

RICHARDS, L.O. 1970. A new face for the church. Grand Rapids, Michigan : Zondervan.

SHAWCHUCK, N. \& HEUSER, R. 1993. Leading the congregation. Caring for yourself while serving the people. Nashville : Abingdon.

SINE, T. 1999. Mustard seed versus McWorld. Reinventing life and faith for the future. Grand Rapids : Baker Books.

SMIT, N. 2001. Poverty and inequality in South Africa: a vision for the future. Word in Action, 41(378):9-11.

SMIT, C.J. \& VORSTER, J.M. 2000. Die GKSA en sy gereformeerde identiteit. In die Skriflig, 34(4):515-533.

SPOELSTRA, B. 1989. Gereformeerde kerkreg en kerkregering. 'n Handboek by die kerkorde. Hammanskraal : Hammanskraalse Teologiese Skool van die GKSA.

SWEET, L. 1999. Soul Tsunami. [Web]: http://www.soultsunami.com/ section1.html [Date of access: 27/07/1999].

THERON, J.P. 1992. Die kerkgebou van more lyk ... anders. Die Kerkbode, 149(14):10.

THISELTON, A.C. 1995. Interpreting God and the postmodern self. On meaning, manipulation and promise. Grand Rapids, Michigan : Eerdmans.

U2. 1993. Zooropa. Island Records. [CD-Rom].

VAN DER WALT, B.J. 1999. Kerkvernuwing onderweg na 2000. Visie - Missie - Konteks. Potchefstroom : IRS. 
VAN DER WALT, J.G.L. 1992. Verstedeliking - 'n eties-pastorale studie. Potchefstroom : PU vir CHO. (Th.B.-werkstuk.)

VORSTER, J.M. 1993. Die koninkryk van God as paradigma vir kerkvernuwing. Nederduitse Gereformeerde Teologiese Tydskrif, 34(4):523-531.

\section{Kernbegrippe:}

gemeentebou

kerklike bediening

postmodernisme

verstedeliking

\section{Key concepts:}

church building church ministry post-modernism urbanization 